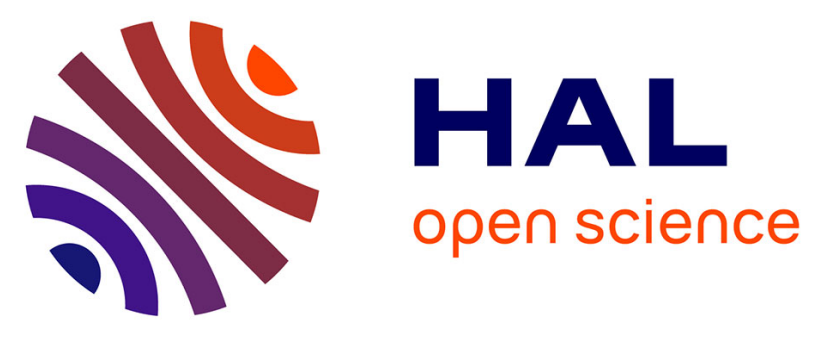

\title{
Experimental and modelling evidence of splash effects on manure borne Escherichia coli washoff
}

Claude Mügler, Olivier Ribolzi, Marion Viguier, Jean-Louis Janeau, Emilie Jardé, Keooudone Latsachack, Thierry Henry-Des-Tureaux, Chanthamousone Thammahacksa, Christian Valentin, Oloth Sengtaheuanghoung, et al.

\section{To cite this version:}

Claude Mügler, Olivier Ribolzi, Marion Viguier, Jean-Louis Janeau, Emilie Jardé, et al.. Experimental and modelling evidence of splash effects on manure borne Escherichia coli washoff. Environmental Science and Pollution Research, 2021, 28 (25), pp.33009-33020. 10.1007/s11356-021-13011-8 . hal03154682

\section{HAL Id: hal-03154682 \\ https://hal.science/hal-03154682}

Submitted on 1 Jul 2021

HAL is a multi-disciplinary open access archive for the deposit and dissemination of scientific research documents, whether they are published or not. The documents may come from teaching and research institutions in France or abroad, or from public or private research centers.
L'archive ouverte pluridisciplinaire HAL, est destinée au dépôt et à la diffusion de documents scientifiques de niveau recherche, publiés ou non, émanant des établissements d'enseignement et de recherche français ou étrangers, des laboratoires publics ou privés. 


\section{Experimental and modelling evidence of splash effects on manure borne}

\section{Escherichia coli washoff}

3 Claude Mügler ${ }^{\mathrm{a} *}$, Olivier Ribolzi ${ }^{\mathrm{b}}$, Marion Viguier ${ }^{\mathrm{b}}$, Jean-Louis Janeau ${ }^{\mathrm{c}}$, Emilie Jardéd,

4 Keooudone Latsachack ${ }^{\mathrm{e}}$, Thierry Henry-Des-Tureaux ${ }^{\mathrm{c}}$, Chanthamousone Thammahacksa ${ }^{\mathrm{e}}$,

5 Christian Valentin ${ }^{\mathrm{c}}$, Oloth Sengtaheuanghoung ${ }^{\mathrm{f}}$, Emma Rochelle-Newall $^{\mathrm{c}}$

6

${ }^{a}$ Laboratoire des Sciences du Climat et de l'Environnement, UMR 8212 CEA-CNRS-UVSQ,

8 Orme des Merisiers, 91191 Gif-sur-Yvette Cedex, France

9 bGET (IRD, Université de Toulouse, CNRS, UPS), 14 avenue Edouard Belin, 31400

10 Toulouse, France

11 'Sorbonne Université, Univ Paris Est Creteil, IRD, CNRS, INRA, Institute of Ecology and

12 Environmental Sciences (iEES-Paris), F-75005, Paris, France

13 dUniv Rennes, CNRS, Géosciences Rennes, UMR 6118, 35000 Rennes, France

14 'IRD, iEES-Paris, Department of Agricultural Land Management (DALaM), P.O. Box 4199,

15 Ban Nongviengkham, Xaythany District, Vientiane, Lao PDR

16 f Agriculture Land-Use Planning Center (ALUPC), Ministry of Agriculture and Forestry,

17 Vientiane, Lao PDR

$18 *$ Corresponding author: Claude Mügler

19 E-mail address: claude.mugler@cea.fr

20 Phone number: $33(0) 169089363$

21 Full postal address: Laboratoire des Sciences du Climat et de l'Environnement, Centre de

22 Saclay, Orme des Merisiers, Bât.714, 91191 Gif-sur-Yvette Cedex, France 
Summary: In tropical montane South-East Asia, recent changes in land use have induced increased runoff, soil erosion and in-stream suspended sediment loads. Land use change is also contributing to increased microbial pathogen dissemination and contamination of stream waters. Escherichia coli (E. coli) is frequently used as an indicator of faecal contamination. Field rain simulations were conducted to examine how E. coli is exported from the surface of upland, agricultural soils during runoff events. The objectives were to characterize the loss dynamics of this indicator from agricultural soils contaminated with livestock waste, and to identify the effect of splash on washoff. Experiments were performed on nine $1 \mathrm{~m}^{2}$ plots, amended or not with pig or poultry manure. Each plot was divided into two $0.5 \mathrm{~m}^{2}$ sub-plots. One of the two sub-plots was protected with a mosquito net for limiting the raindrop impact effects. Runoff, soil detachment by raindrop impact and its entrainment by runoff, and E. coli loads and discharge were measured for each sub-plot. The results show that raindrop impact strongly enhances runoff generation, soil detachment and entrainment and E. coli export. When the impact of raindrops was reduced with a mosquito net, total runoff was reduced by more than $50 \%$, soil erosion was on average reduced by $90 \%$ and $E$. coli export from the amended soil surface was on average 3 to 8 times lower. A coupled physics-based approach was performed using the Cast3M platform for modelling the time evolutions of runoff, solid particles detachment and transfer, and bacteria transport that were measured for one of the nine plots. After estimation of the saturated hydraulic conductivity, soil erodibility, and attachment rate of bacteria, model outputs were consistent with measured runoff coefficients, suspended sediment and E. coli loads. This work therefore underlines the need to maintain adequate vegetation at the soil surface to avoid the erosion and export of soil borne potential pathogens towards downstream aquatic systems.

Keywords: Faecal Indicator Bacteria (FIB); Raindrop impact; Runoff; Physics-based modelling; Tropical agro-ecosystems; Lao PDR 


\section{Introduction}

50 Globally, there are nearly 1.7 billion cases of diarrhoeal disease every year making it the second leading cause of death in children under five years old (World Health Organisation 2014). A large proportion of this disease load is directly related to the ingestion of water contaminated with microbial pathogens of faecal origin. In urban areas, the majority of faecal contamination is of human origin. However, in rural areas, livestock can also be a significant source of microbial pollution (Gagliardi and Karns 2000; Unc and Goss 2004).

Several bacteria are used as indicators of faecal contamination. However, Escherichia coli (E. coli) has emerged as one of the most appropriate indicators of microbial contamination of natural waters (Ishii and Sadowsky 2008; Rochelle-Newall et al. 2015). The presence or absence of faecal indicator bacteria (FIB) indicates whether or not faecal contamination is potentially present.

61 Runoff from manured fields and pastures, as well as direct deposition of animal waste into water are traditionally viewed as important mechanisms of $E$. coli contamination in rural watersheds (Jamieson et al. 2004). The importance of surface runoff during storm events as a mechanism of transport of soil bound E. coli was also highlighted by Causse et al. (2015). Ribolzi et al. (2016) showed that the erosion of particles from the soil surface during storm events is a strong source of E.coli in rural, montane streams. This is of importance as the majority of enteric bacteria in aquatic systems are associated with sediments and these associations influence their survival and transport characteristics (Jamieson et al. 2005; Muirhead et al. 2006; Wilkinson et al. 1995).

70 Several authors have demonstrated that overland flow and splash effect (i.e. impact of 71 raindrops on soil surface) are major determinants for soil surface particle detachment and displacement at the plot scale in inter-rill zones (Lacombe et al. 2018; Luk 1979; Quansah 1981; Ziegler et al. 2000). Detached soil particles are then transported downstream by the 
splash related droplets and overland flow. Splash and overland flow are interacting processes: kinetic energy dissipation of raindrop impact induces the soil surface sealing, which drastically reduces infiltration (Assouline and Mualem 1997) and favours ponding and overland flow (Mügler et al. 2019); splash results from the compression of the water at the soil surface and thus requires an optimal film thickness for the greatest efficiency which is in the order of $10 \mathrm{~mm}$ (Kinnell 1993). Other factors influence the intensity of splash detachment: (i) kinetic energy of drops, which can be increased or reduced depending on the ground cover (Lacombe et al. 2018) or slope angle (Ribolzi et al. 2011); (ii) soil texture, with fine sands being the most sensitive; (iii) soil organic matter content that increases the cohesion of soil particles (Armenise et al. 2018); (iv) soil moisture with low splash detachment when soils are dry and increasingly higher with increasing soil moisture. These processes are often measured on plots of $1 \mathrm{~m}^{2}$ (Patin et al. 2018).

During the rainy season in tropical humid regions, rainfall intensities are high and the splash effect is known to be a determining factor for the detachment of soil particles (Ziegler et al. 2000). Therefore, given the anticipated links between rain intensity, erosion and the export of soil surface $E$. coli during rain events, it can be hypothesised that the splash effect will have a strong impact on the export of E. coli from the soil surface.

Modelling experiments with a physics-based approach is a useful way to understand the physical processes involved. Numerical simulations allow to test different hypotheses on runoff production and the transport of sediments and bacteria. For example, Guber et al. (2009, 2011) coupled the kinematic wave overland flow model KINEROS2 with a convective-dispersive overland transport equation for modelling overland transport of bacteria. The model successfully simulated the release and transport of faecal coliforms on vegetated and bare plots. In a recent paper, we used the physics-based Cast $3 \mathrm{M}$ code for modelling the impact of raindrops on hydraulic conductivity and overland flow intensity on 
steep slopes under high-intensity rainfall (Mügler et al. 2019). The present paper follows on from that work and characterizes the transport of FIB using complementary experimental and modelling approaches.

Rain simulation experiments have been used to examine soil erosion, organic matter export and the impact of various land use practices on soil erosion (Janeau et al. 2014; Le et al. 2020; Tatard et al. 2008). In the present paper, we applied this technique to understand how an indicator of faecal contamination is exported from upland soils used for agricultural activities during a rain event. The objectives of this work were to characterize the loss dynamics of $E$. coli from agricultural soils contaminated with livestock waste and to partition total detachment into the splash and hydraulic components.

\section{Materials and methods}

\subsection{Study area}

The rain simulation experiments were conducted in a small mountain Laotian catchment, the Houay Pano catchment (Fig. 1a). This catchment belongs to the Critical Zone Observatory MTropics (Multiscale TROPIcal Catchments, https://mtropics.obs-mip.fr). It can be considered as being representative of the montane rural agro-ecosystems of South-East Asia (steep slopes, high rainfall intensities during the rainy season, « slash and burn » agricultural system, contaminated water with microbial pathogens of faecal origin). Shale and schist soil are the most widespread in the catchment and the soil is slightly acidic (Ribolzi et al. 2011). The study area is subject to a tropical climate with heavy rains up to $280 \mathrm{~mm} \mathrm{~h}^{-1}$ (Valentin et al. 2008). Experiments were carried out during the dry season. The agricultural production system is based on a slash and burn technique. Main land use has recently switched from crops and fallow toward teak plantations (Ribolzi et al. 2017). Animal husbandry is now developing. However, animal density remains low with two or three pigs in the lower sections 
123 of the catchment and some chickens $(\sim 20)$ in both the lower and upper sections (Rochelle-

124 Newall et al. 2016).

125

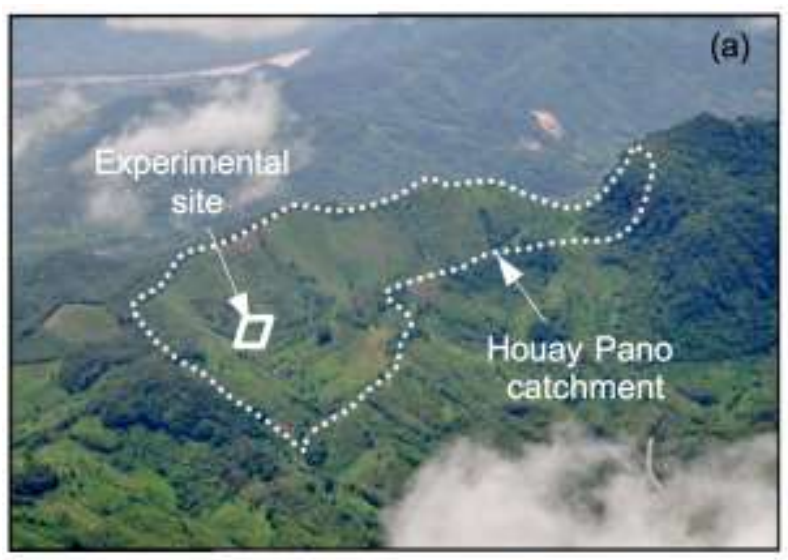

126

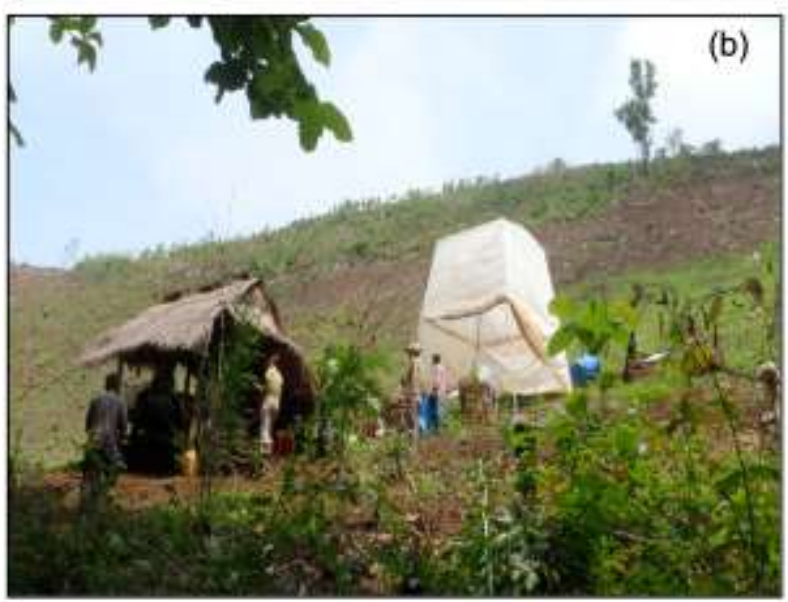

127 Fig. 1 Study site: (a) Aerial view of the Houay Pano catchment (white dotted polygon) and

128 location of the experimental site (white rhombus); (b) Picture showing an overview of the

129 hillslope and the experimental site with the rainfall simulator tent on the right

\subsection{Experimental design}

132 Nine $1 \mathrm{~m}^{2}$ plots were implanted following the method of Janeau et al. (2003) on a steep slope

133 of the upper part of the catchment (Fig. 1b). All the plots had roughly the same steep slope

134 ( $48 \%)$. The purpose of the study was not to investigate the influence of the slope on the

135 intensity of splash detachment. Indeed, this point has already been studied at Houay Pano by 
136 Ribolzi et al. (2011). The soil characteristics (slope, bulk density and texture) are given in

137 Table SI-1 (Online Resource 1). The experimental design was similar to that used by Mügler

138 et al. (2019). Each plot was divided into two sub-plots $(1 \mathrm{~m}$ downslope $\times 0.5 \mathrm{~m}$ perpendicular

139 to the slope) and one of the sub-plot was covered with a 2-mm grid size wire screen (a

140 mosquito net) (Fig. 2a). The role of the net was to reduce the raindrop impact effects on the

141 soil surface. The nine plots (Fig. 2b) were divided into triplicated treatment groups, denoted

142 A, B, and C: controls with no amendments (Ref A, Ref B and Ref C) or amended with pig

143 manure (Pig A, Pig B, and Pig C) or poultry manure (Chi A, Chi B, and Chi C).

144

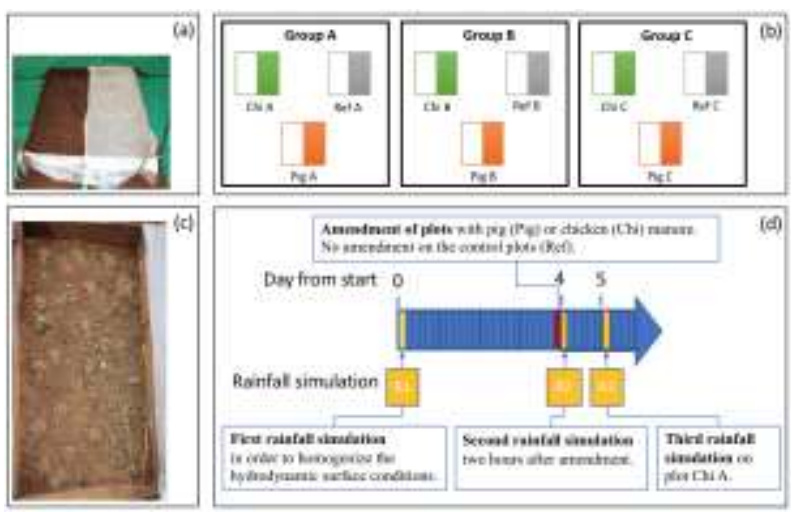

146 Fig. 2 Experimental design: (a) image of one $1-\mathrm{m}^{2}$ metallic frame divided into two sub-plots

147 without mosquito net (left) and with mosquito net (right); (b) Diagram showing the nine plots

148 (pairs of 9 sub-plots without mosquito net shown in white, associated with 9 sub-plots covered

149 with mosquito net shown in colour) divided in triplicated treatment groups (A, B, C): controls

150 with no amendments (Ref A, Ref B, and Ref C) or amended with pig manure (Pig A, Pig B, and

151 Pig C) or poultry manure (Chi A, Chi B, and Chi C); (c) Image of one sub-plot partially covered

152 with disconnected small patches of chicken manure ; (d) Chronological sequence for the three

153 rainfall simulations (R1, R2 and R3) and time of amendment with pig or chicken manure 
155 A portable rainfall simulator was used for the three successive rainfall simulations (Fig. 1b).

156 The characteristics of the rainfall simulations were similar to those used and described in

157 Mügler et al. (2019): a constant rainfall intensity $\sim 90 \mathrm{~mm} \mathrm{~h}^{-1}$ during $60 \mathrm{~min}$. The plots were

158 protected with a plastic cover between simulations to prevent the possible modification of the

159 soil surface characteristics and moisture content from natural precipitation. The rain water

160 used for the simulations was pumped from an upland stream adjacent to the plots and samples

161 were collected to determine the background levels of contamination for the rain simulations

162 (Table SI-2, Online Resource 1).

163 The hydrodynamic surface conditions of the nine plots were homogenized by the first rainfall

164 simulation, denoted R1, which was performed without amendment (Fig. 2d). The second

165 rainfall simulation, denoted $\mathrm{R} 2$, was carried out on the nine plots 4 days after R1. It was

166 conducted two hours after the input of livestock waste to the Chi and Pig plots (Fig. 2d). No

167 manure was added to the control Ref plots. For the Chi plot of group A, denoted Chi A plot, a

168 third rainfall simulation, denoted R3, was conducted 24 hours after R2 (Fig. 2d).

169 Overland flow from each $0.5 \mathrm{~m}^{2}$ sub-plot was collected in a large and clean bucket during

170 each rain simulation. Samples of water were collected from each bucket at the end of each

171 rainfall simulation for the determination of total suspended sediment concentration (TSS, $g$

$172 \mathrm{1}^{-1}$ ), and E. coli numbers (MPN $100 \mathrm{ml}^{-1}$ ). These samples represent the average concentration

173 in the runoff water from the $0.5 \mathrm{~m}^{2}$ sub-plot. During the rainfall simulations $\mathrm{R} 2$ and $\mathrm{R} 3$ on the

174 Chi A plot, in addition to the average sample, five additional samples were collected over the

175 duration of the simulation to provide an estimation of the time course of $E$. coli export in

176 runoff during two successive rain events. The time course measurements during R3 were only

177 conducted on the Chi A plot. The other plots were destroyed by a very strong natural rainfall

178 event before third series of rain simulations could be completed. As a consequence of the 
complexity of running this type of experiment in a tropical, upland rural terrain, the rainfall

180 simulations were performed on consecutive days (Fig. 2d). However, care was taken to ensure

181 that the interval of time between simulations was the same throughout the experiment.

182

183

184

185

186

187

188

189

190

191

192

193

194

195

196

197

198

\subsection{Manure treatments}

Pig and chicken manure was collected from six properties in the village of Ban Lak Sip. The manure from each animal type was pooled and mixed. For each $0.5 \mathrm{~m}^{2}$ sub-plot, $84 \mathrm{~g}$ of pig manure or $62 \mathrm{~g}$ of chicken waste were mixed with $250 \mathrm{ml}$ of water used for rainfall simulation. These amounts were selected in order to compensate for the higher anticipated E. coli loading in chicken manure (Rosebury 1962). Table 1 gives the E. coli loads of the manure applied to the plots before the second rainfall simulation, R2. Amended plots were only partially covered by disconnected small patches of manure (Fig. 2c).

Table 1: Most probable number (MPN) of E. coli with the associated uncertainty for the soil of the study area and the collected pig (Pig) and poultry (Chi) faeces (wet-weight).

\begin{tabular}{llll}
\hline & $\begin{array}{l}\text { Measured E. coli } \\
\left(\mathrm{MPN} \mathrm{g}^{-1}\right)\end{array}$ & Error $(-)$ & Error $(+)$ \\
\hline Soil & 5133 & 1027 & 12133 \\
Chicken & $1.80 \times 10^{9}$ & $1.02 \times 10^{9}$ & $2.80 \times 10^{9}$ \\
Pig & $0.27 \times 10^{9}$ & $0.17 \times 10^{9}$ & $0.43 \times 10^{9}$ \\
\hline
\end{tabular}

\subsection{Determination of TSS and E. coli}

The concentration of Total Suspended Sediments (TSS) was measured in each $330 \mathrm{ml}$ sample after filtration on $0.45 \mu \mathrm{m}$ porosity cellulose acetate pre-weighted filters (Sartorius) and evaporation at $105{ }^{\circ} \mathrm{C}$ for $48 \mathrm{~h}$. 
E. coli was quantified by standardised microplate method (ISO 8308-3, MUGEC; BioKar®).

200 This method, which has been used with success in this watershed (Boithias et al. 2016;

201 Causse et al. 2015; Ribolzi et al. 2016), is briefly described below. $200 \mu 1$ of sample were

202 inoculated into each well of the 96-well plate. Six serial dilutions from 1/20 to 1/200000 were

203 used and one plate was used per sample, giving 16 wells per dilution. The limit of detection is

204 low: $15 \mathrm{MPN} 100 \mathrm{ml}^{-1}$. Samples were treated within four hours of collection and were

205 incubated at $44^{\circ} \mathrm{C}$ for 48 hours. E. coli was determined from the number of positive wells

206 using a statistical Poisson distribution (MPN calculator, Build 22 by Mike Curiale).

\subsection{Flow, erosion and bacteria transport modelling}

208 The coupling of surface and subsurface flows was performed within a Darcy multidomain 209 approach (Weill et al. 2009). In this approach, flow in the runoff layer, in the unsaturated zone, 210 and in the saturated zone are modelled with a diffusive wave approximation of the Saint-Venant 211 equations, the Darcy equation, and the Richards equation, respectively. The characteristic of the

212 Darcy multidomain approach is to write all these equations in the same way in the whole

213 domain as a single Richards diffusion type equation that describes both surface and subsurface

214 flows. A fuller description of the method is provided in the Supplementary Methods section

215 (Online Resource 1). In the present paper, as validated in Mügler et al. (2019), the saturated

216 hydraulic conductivity $K_{S}$ was assumed constant in space at the $1-\mathrm{m}^{2}$ plot scale but was assumed

217 to decrease with time during the rainfall event due to seal formation according to the following 218 exponential function:

$K_{S}(t)=K_{\infty}+\left(K_{0}-K_{\infty}\right) e^{-\left(R t / \tau_{1}\right)}$

220 where $R$ is the rainfall rate [LT $\left.{ }^{-1}\right], \tau_{1}$, a dimensioning parameter [L], and $K_{0}$ and $K_{\infty}$, the initial 221 and final hydraulic conductivities $\left[\mathrm{LT}^{-1}\right]$, respectively (Assouline 2004; Mügler et al. 2019;

222 Ribolzi et al. 2011; Silburn and Connolly 1995). 
223 Erosion by soil detachment and entrainment in the runoff layer was modelled with the following

224 sediment mass balance equation

$225 \frac{\partial h c}{\partial t}+\frac{\partial q c}{\partial x}=e(x, t)$

226 where $c$ is the depth-averaged sediment concentration $\left[\mathrm{L}^{3}\right.$ of sediment $/ \mathrm{L}^{3}$ of water $], h$ is the 227 water depth in the runoff layer [L], and $q=h \times u$ is the water flux $\left[\mathrm{L}^{2} \mathrm{~T}^{-1}\right]$, with $u$, the runoff 228 velocity. The source term $e\left[\mathrm{LT}^{-1}\right]$ is usually divided into two contributions: the rate of particle detachment by raindrop impact (hereinafter called splash erosion $e_{s}$ ), and the net rate of particle detachment by flow (hereinafter called hydraulic erosion $e_{h}$ ). At small scale, the dominant

231 erosion mechanism is splash (Kinnell 2005). As a consequence, at the $1-\mathrm{m}^{2}$ plot scale, we 232 neglected the hydraulic erosion $e_{h}$, and only modelled the splash erosion $e_{s}$. Splash erosion is 233 modelled in the same way as in the KINEROS code (Woolhiser et al. 1990)

$234 e_{s}(x, t)=c_{f}(t) \times k(h) \times(R-I)^{2}$

235 where $R$ and $I$ are the rainfall rate and the infiltration rate in the soil $\left[\mathrm{LT}^{-1}\right]$, respectively. For 236 modelling surface crusting during the rainfall event, we made the choice to model the soil 237 erodibility $c_{f}(t)\left[\mathrm{L}^{-1} \mathrm{~T}\right]$ in the same way as we modelled the saturated hydraulic conductivity $238 \quad K_{s}(t)($ Eq. $(1))$

$c_{f}(t)=c_{\infty}+\left(c_{0}-c_{\infty}\right) e^{-\left(R t / \tau_{2}\right)}$

240 where $\tau_{2}$ is a dimensioning parameter [L], and $c_{0}$ and $c_{\infty}$ are the initial and final soil 241 erodibilities $\left[\mathrm{L}^{-1} \mathrm{~T}\right]$, respectively.

242 The function $k(h)$ in Eq. (3) models the decrease of splash erosion rate as surface water depth 243 increases according to the following formulation

$244 k(h)=e^{-c_{h} \times h}$

245 where $c_{h}$ is the damping coefficient $\left[\mathrm{L}^{-1}\right]$, which is estimated according to Woolhiser et al. 246 (1990) as follows 
248 where $d_{r}$ is the raindrop diameter.

249 Transport of bacteria in the runoff layer was modelled with the following mass balance equation $250 \quad$ (Guber et al. 2011)

$\frac{\partial h C_{b}}{\partial t}+\frac{\partial q C_{b}}{\partial x}=\frac{\partial}{\partial x}\left(a_{L} q \frac{\partial C_{b}}{\partial x}\right)-\frac{\partial S_{m}}{\partial t}-d\left(k_{a} C_{b}-k_{d} \rho S_{s}\right)-\left(1-k_{s}\right) I C_{b}+R C_{i r}$

252 where $C_{b}, S_{m}, S_{s}$, and $C_{i r}$ are the cell concentrations in the runoff layer, in the manure applied to 253 the soil surface, in the solid phase of the soil mixing zone, and in the rainfall water, respectively.

254 The mixing zone is the soil surface layer that actively interacts with runoff. Its depth and the soil 255 bulk density in this zone are denoted $d$ and $\rho$, respectively. The parameters $a_{L}, k_{a}, k_{d}$, and $k_{s}$ are 256 the dispersivity [L], the attachment and detachment rates of bacteria at the solid phase [T $\left.{ }^{-1}\right]$, and 257 the straining coefficient that models the filter due to vegetation, respectively.

258 The mass conservation of bacteria in the soil mixing zone was given by

$d \rho \frac{\partial S_{s}}{\partial t}=d\left(k_{a} C_{b}-k_{d} \rho S_{s}\right)+k_{f}\left(1-k_{s}\right) I C_{b}$

260 where $k_{f}$ denotes the fraction of infiltrated cells that are filtered out within the soil-mixing zone.

261 However, Martinez et al. (2014) concluded after a global sensitivity analysis that this parameter

262 was not relevant. Furthermore, the best calibrations of simulations of transport of bacteria

263 performed by Guber et al. $(2009,2011)$ were obtained with $k_{s} \sim 1$, showing that the main bacteria 264 exchange between runoff and soil is attachment of bacteria at the solid phase. As a consequence, 265 we took both $k_{f}$ and $k_{s}$ equal to one.

266 The irreversible release of bacteria from the surface applied manure was modelled according to 267 Guber et al. (2011) as follows

$268 \quad \frac{\partial S_{m}}{\partial t}=-C_{0} h_{m} \alpha_{m}\left(1+\alpha_{m} \beta_{m} t\right)^{-\left(1+1 / \beta_{m}\right)}$ 
269

270

271

272

273

274

275

276

277

278

279

280

281

282

283

284

285

286

287

288

289

290

where $C_{0}$ is the initial cell concentration in the applied manure [cell $\mathrm{L}^{-3}$ ], $h_{m}$ is the thickness of the applied manure, and $\alpha_{m}$ and $\beta_{m}$ are two parameters that characterize the shape of the release curve.

All equations were solved with the numerical code Cast3M. More information about the numerical method and its validation can be found in (Kollet et al. 2017; Mügler et al. 2011;

Mügler et al. 2019; Weill et al. 2009). The bacteria transport module was validated with experimental data already published (Guber et al. 2009). Results are described in the Supplementary Methods section (Online Resource 1).

\section{Results}

\subsection{Runoff and erosion}

In general, runoff increased from the first simulation (R1) to the second simulation (R2) in all of the plots, regardless of amendment or whether or not netting was present. The average and the standard deviation of the runoff volume from the nine sub-plots where the splash effect was present (those without the netting) was equal to $43( \pm 12) \mathrm{mm}$ during $\mathrm{R} 1$ and increased to $52( \pm 13)$ mm during R2 (Fig.3a, left side). In the sub-plots where the splash effect was reduced (those with netting), this average runoff volume increased from $12( \pm 2) \mathrm{mm}$ to 25 ( \pm 6$) \mathrm{mm}$ (Fig.3a, right side). The pattern was less clear for soil detachment, although there was for most cases a slight tendency towards decreased soil detachment in R2. Average soil detachment and entrainment in the nine sub-plots where the splash effect was present was equal to $62( \pm 38) \mathrm{g} \mathrm{m}^{-2}$ during R1 and decreased to $54( \pm 34.0) \mathrm{g} \mathrm{m}^{-2}$ during R2 (Fig.3b, left side). In the sub-plots where the splash effect was reduced, this average soil erosion was very low both during R1 $\left(4( \pm 4) \mathrm{g} \mathrm{m}^{-2}\right)$ and $\mathrm{R} 2\left(6( \pm 5) \mathrm{g} \mathrm{m}^{-2}\right)$ (Fig. 3b, right side). 


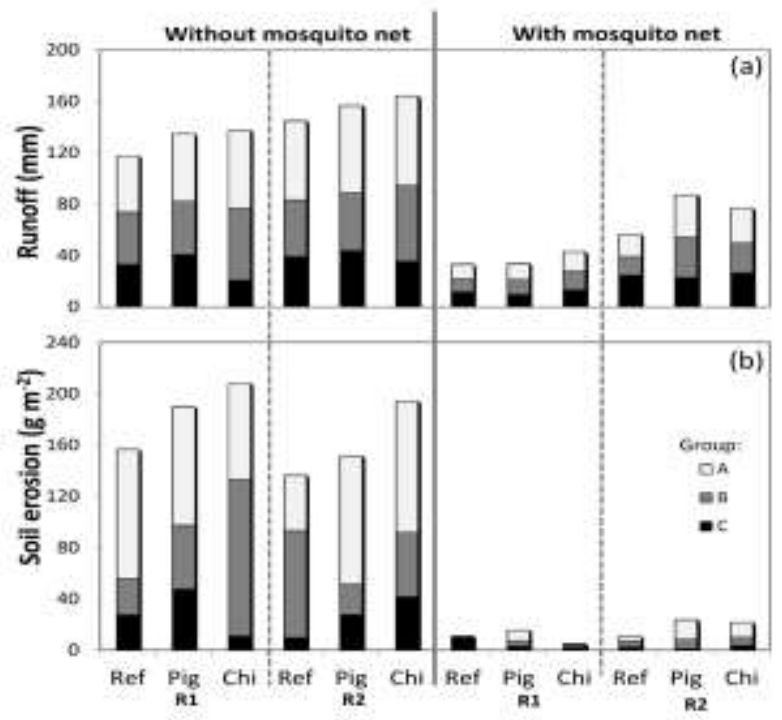

293 Fig. 3 Bar plots showing cumulated (a) runoff depth and (b) soil erosion from the eighteen

$2940.5 \mathrm{~m}^{2}$ sub-plots (i.e. nine without plus nine with mosquito net) divided into triplicated

295 treatment groups (A, B, C). Controls with no amendments (Ref) or amended with pig manure

296 (Pig) or poultry manure (Chi). Measurements were conducted during the first rainfall

297 simulation (R1, before manure application) and the second rainfall simulation (R2, after

298 manure application)

300 Large differences in runoff volume and soil erosion were observed between the sub-plots with

301 and without mosquito netting (Fig. 3). This pattern of higher runoff in the splash sub-plots

302 was common to all treatments and all rainfall simulations, regardless of whether manure was

303 added or not. The average runoff volume was $\sim 4$ and $\sim 2$ times higher in the nine sub-plots

304 where the splash effect was present than in the nine sub-plots where the splash effect was

305 reduced during the first (R1) and second rainfall simulation (R2), respectively. Similarly,

306 average soil erosion on the nine sub-plots where the splash effect was present was nearly one

307 order of magnitude higher than in the sub-plots where the splash effect was reduced after both

$308 \mathrm{R} 1$ and R2. 
310 The chicken faeces used contained more than six times more E. coli than pig faeces (Table 1).

311 The average concentrations of $E$. coli in runoff collected in the sample bucket at the end of R2 312 were four orders of magnitude higher in the plots that were amended with manure (Fig. 4).

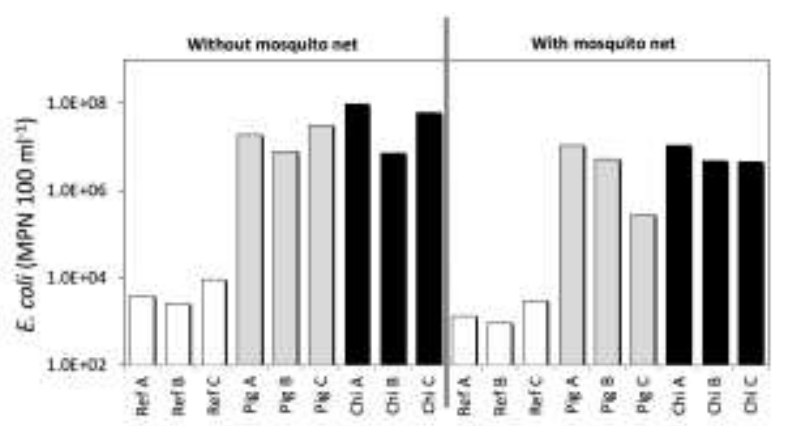

315 Fig. 4 E. coli concentration in runoff water from both sub-plots without mosquito net (left

316 side, with splash effect) and with mosquito net (right side, with limited splash effect) for the triplicated plots Ref, Pig, and Chi for rainfall simulation R2

The average concentrations of $E$. coli in runoff from the Ref plots were $5.2 \times 10^{3}\left( \pm 3.5 \times 10^{3}\right)$ and $1.7 \times 10^{3}\left( \pm 1.1 \times 10^{3}\right)$ MPN $100 \mathrm{ml}^{-1}$ for the splash and non-splash plots, respectively. These values are of the same order of magnitude as the $E$. coli concentrations measured in the stream water used for the rain during these Ref rainfall simulations (Table SI-2, Online Resource 1). E. coli concentrations increased to $1.9 \times 10^{7}\left( \pm 1.1 \times 10^{7}\right)$ and $5.5 \times 10^{6}( \pm 5.4 \times$ $\left.10^{6}\right) \mathrm{MPN} 100 \mathrm{ml}^{-1}$ for the Pig splash and non-splash plots and $5.5 \times 10^{7}\left( \pm 4.6 \times 10^{7}\right)$ and 6.7 x $10^{6}\left( \pm 3.7 \times 10^{6}\right)$ MPN $100 \mathrm{ml}^{-1}$ for the Chi splash and non-splash, respectively. Comparing 326 the splash and non-splash plots, the concentrations of E. coli were 3, 3.5 and 8 times lower for 327 Ref, Pig and Chi, respectively.

328 The concentration of $E$. coli in runoff was significantly correlated with suspended sediment concentrations in the splash sub-plots $\left(\mathrm{r}^{2}=0.68 ; \mathrm{p}<0.05\right)$ for R2 and R3 on the Chi A sub- 
330 plots. No significant correlation was observed for the non-splash sub-plots (Fig. SI-2, Online

331 Resource 1).

332

333

\subsection{Surface runoff modelling}

The modelling approach was used to simulate the time course experiment performed on the two

Chi A sub-plots during two successive rainfall simulations R2 and R3. Figures 5a-b display both experiment and model overland flow coefficients. This coefficient is equal to the ratio between the overland flow rate and the rainfall rate. Model outputs were obtained with the parameter values listed in Table SI-3 in the Supplementary Methods section (Online Resource 1). These values are the same as those already used and discussed in Mügler et al. (2019). Only the saturated hydraulic conductivity was estimated. The characteristics of the time evolutions $\mathrm{K}_{\mathrm{s}}(\mathrm{t})$ used for modelling the runoff (cf. Eq. (1)) are given in Table 2. Runoff in the sub-plot without a mosquito net (splash plots) was correctly modelled with a fast decreasing $\mathrm{K}_{\mathrm{S}}(\mathrm{t})$, with the same $\tau_{1}$ value for the two successive rainfalls $\left(\tau_{1}=21.4 \mathrm{~mm}\right)$, and with values of $\mathrm{K}_{0}$ and $\mathrm{K}_{\infty}$ that were higher in the modelling of R2 than in R3. On the contrary, runoff in the sub-plot with a mosquito net was correctly modelled with a slow decreasing $\mathrm{K}_{\mathrm{S}}(\mathrm{t})$, with a nearly one order of magnitude higher value for $\tau_{1}\left(\tau_{1}=187.5 \mathrm{~mm}\right)$. Here again, the value of $\mathrm{K}_{0}$ decreased from $\mathrm{R} 2$ to R3. However, the value for $K_{\infty}$ was the same for both rainfalls. The smaller values of $K_{0}$ in the modelling of runoff on the sub-plot without a mosquito net are probably due to the raindrop impact during the preliminary rainfall (before the manure application). 

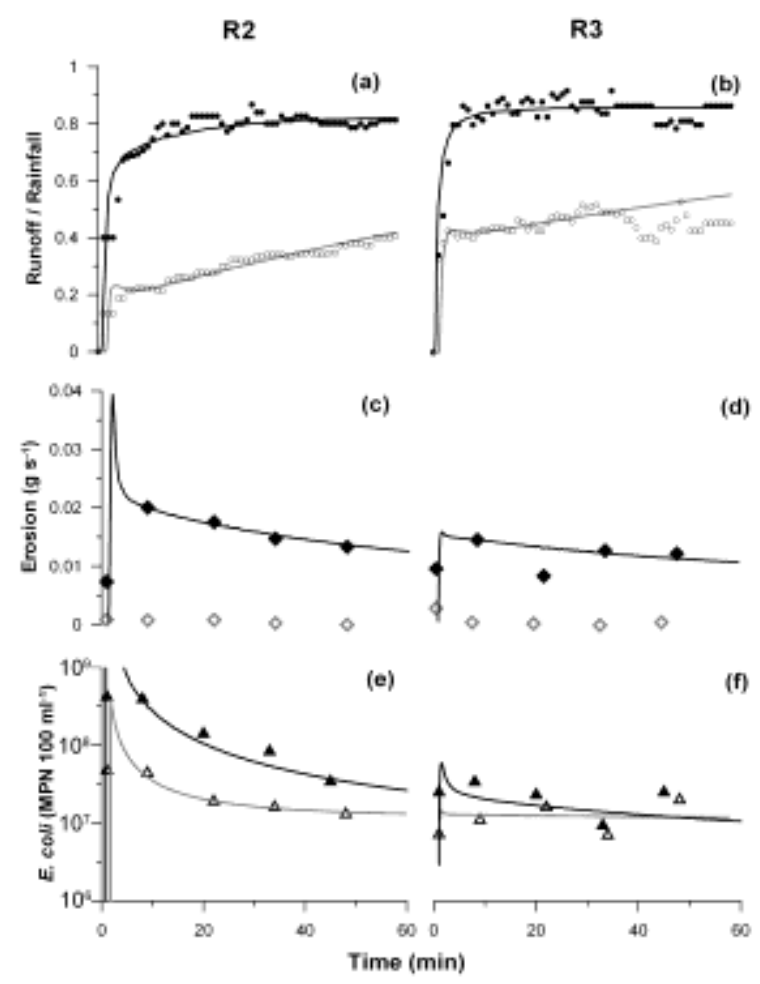

Fig. 5 Evolution over time on plot Chi A of the runoff coefficient (Runoff/Rainfall) obtained

352 during R2 (a) and R3 (b); the sediment outputs obtained during R2 (c) and R3 (d); E. coli

353 concentrations obtained during R2 (e) and R3 (f). In each figure, empty and filled symbols

354 correspond to the experimental results for the sub-plots with and without a mosquito net,

355 respectively. Solid lines correspond to the modelled evolutions with mosquito net (grey) and

356 without mosquito net (black)

357 Table 2: Estimated parameter values for the time evolution of saturated hydraulic conductivity

$358 \mathrm{~K}_{\mathrm{S}}(\mathrm{t})$ given by Eq. (1) and obtained for the two Chi A sub-plot experiments, with and without

359 raindrop impact, and for two successive rainfall simulations R2 and R3.

\begin{tabular}{lllll}
\hline Sub-plot & Rainfall simulation & $\tau_{1}(\mathrm{~mm})$ & $\mathrm{K}_{0}\left(\mathrm{~mm} \mathrm{~h}^{-1}\right)$ & $\mathrm{K}_{\infty}\left(\mathrm{mm} \mathrm{h}^{-1}\right)$ \\
\hline without a mosquito net & $\mathrm{R} 2$ & 21.4 & 40 & 18 \\
without a mosquito net & $\mathrm{R} 3$ & 21.4 & 20 & 14 \\
\hline with a mosquito net & R2 & 187.5 & 84 & 16 \\
with a mosquito net & $\mathrm{R} 3$ & 187.5 & 62 & 16 \\
\hline
\end{tabular}




\subsection{Erosion modelling}

362 Figures 5c-d show the evolutions over time of both measured and modelled sediment outputs

363 during R2 and R3 on the Chi A sub-plots. The comparison of sediment outputs with or without a 364 mosquito net clearly shows the large effect of raindrop impact on erosion. Sediment outputs

365 from the sub-plot for which the surface soil is protected from raindrop impact by a mosquito net

366 are negligible indicating that splash erosion is negligible when the raindrop impact is reduced. It

367 also supports the assumption that hydraulic erosion is negligible at the $1-\mathrm{m}^{2}$ plot scale. As a

368 consequence, only the experiment with the raindrop impact was modelled with Eqs (2)-(6).

369 For a $\sim 90 \mathrm{~mm} \mathrm{~h}^{-1}$ rainfall rate, the raindrop diameter $d_{r}$ is approximately equal to $1.34 \mathrm{~mm}$

370 (Mügler et al. 2019). Thus, according to Eq. (6), the damping coefficient $c_{h} \sim 1493 \mathrm{~m}^{-1}$. Table 3

371 lists the values of the other erosion parameters which were estimated from the experimental

372 time evolutions of the sediment outputs plotted in Figs. 5c-d.

374 Table 3: Estimated parameter values for the time evolution of soil erodibility $\mathrm{c}_{\mathrm{f}}(\mathrm{t})$ given by

375 Eq. (4) and obtained for the sub-plot experiment without a mosquito net, and for two successive 376 rainfall simulations $\mathrm{R} 2$ and $\mathrm{R} 3$.

\begin{tabular}{lllll}
\hline Sub-plot & Rainfall simulation & $\tau_{2}(\mathrm{~mm})$ & $\mathrm{c}_{0}\left(\mathrm{~s} \mathrm{~m}^{-1}\right)$ & $\mathrm{c}_{\infty}\left(\mathrm{s} \mathrm{m}^{-1}\right)$ \\
\hline without a mosquito net & R2 & 75 & 21 & 8 \\
without a mosquito net & $\mathrm{R} 3$ & 75 & 15 & 8 \\
\hline
\end{tabular}

378 After rainfall, crusts covered nearly $98 \%$ of the surface of the unprotected sub-plot and $77 \%$ of

379 the surface of the protected sub-plot, which was already crusted prior to the experiments. The 
most impervious crusts, namely gravel and erosion crusts, developed only on the unprotected

381 sub-plot, covering 1.5\% and 6\% of the surface, respectively (Mügler et al. 2019).

\subsection{E. coli transport modelling}

Figures 5e-f show E. coli concentrations in runoff water at the outlet of the Chi A sub-plots

384 during R2 and R3. The numbers of exported E. coli are clearly higher on the sub-plots whose soil surface is not protected from raindrop impact. Table 4 lists the values of two parameter sets, denoted as Model 1 and Model 2 that were used for the bacteria transport modelling. Most of the parameter values in the two sets are the same because they were either measured or determined from the literature. As mentioned in Table 1, the MPN of E. coli in poultry faeces was equal to $1.8 \times 10^{9} \mathrm{MPN} \mathrm{g}^{-1}$, and $62 \mathrm{~g}$ of chicken waste were applied to each sub-plot. As a consequence, we took $C_{0} h_{m}=2.23 \times 10^{11} \mathrm{MPN} \mathrm{m}^{-2}$. Furthermore, as the $E$. coli concentration in

391 the stream water used for the rain during each rainfall simulation was several orders of

392 magnitude lower than $C_{0} h_{m}$ (Table SI-2 in Online Resource 1), the last term in Eq. (7) was

393 removed $\left(C_{i r}=0\right)$.

394 Parameters that characterize the shape of the release curve according to Eq. (9) were estimated 395 from the fit of experimental release of faecal coliform from manure on plots (Guber et al. 2006).

396 Guber et al. (2006) showed that the value of $\alpha_{m}$ in Eq. (9) was linearly related to the rainfall rate $397 R\left(\mathrm{~cm} \mathrm{~h}^{-1}\right)$ according to the following relationship: $\alpha_{m}=0.036+0.86 \times R$. For bare clay loam 398 plots and irrigation rates $\sim 6 \mathrm{~cm} \mathrm{~h}^{-1}$, they found that experimental evolutions were correctly 399 fitted with $\beta_{m}=8$. As a consequence, we took these values (see Table 4). 
Table 4: Parameter values for the bacteria transport modelling.

\begin{tabular}{|c|c|c|c|c|}
\hline Parameters & Symbol & Unit & Model 1 & Model 2 \\
\hline Initial cell concentration & $C_{0} h_{m}$ & MPN m$~^{-2}$ & $2.23 \times 10^{11}$ & same value \\
\hline Cell concentration in the rainfall & $C_{i r}$ & MPN m ${ }^{-2}$ & 0 & same value \\
\hline \multirow[t]{3}{*}{ Shape of the release curve } & $\alpha_{m}$ & $h^{-1}$ & $0.036+0.86 \times R$ & same value \\
\hline & & & $\left(R\right.$ in $\left.\mathrm{cm} \mathrm{h}^{-1}\right)$ & \\
\hline & $\beta_{m}$ & - & 8 & same value \\
\hline Thickness of the active soil & $D$ & M & 0.01 & same value \\
\hline \multicolumn{5}{|l|}{ layer } \\
\hline Dispersivity & $a_{L}$ & M & 0 & same value \\
\hline Partitioning coefficient & $K_{d}$ & $\mathrm{ml} \mathrm{g}^{-1}$ & 54 & same value \\
\hline Attachment rate & $k_{a}$ & $\mathrm{~s}^{-1}$ & 0 & 0.015 (estimated) \\
\hline Detachment rate & $k_{d}=k_{a} /\left(\left(\rho / \theta_{s}\right) \times K_{d}\right)$ & $\mathrm{s}^{-1}$ & 0 & $1.4 \times 10^{-4}$ \\
\hline
\end{tabular}

404

405 The thickness of the soil mixing zone, $d$, was set at $1 \mathrm{~cm}$ (Cho et al. 2016; Guber et al. 2011).

406 Dispersivity was neglected at the $1-\mathrm{m}^{2}$ plot scale $\left(a_{L}=0\right)$. The partitioning coefficient $K_{d}$, which

407 is defined as $k_{a} /\left(\left(\rho / \theta_{\text {sat }}\right) \times k_{d}\right)$, was assumed to be related to the clay content in the soil as follows

408 (Pachepsky et al. 2006)

$409 \quad K_{d}=A \times(C L A Y)^{B}$

410 where CLAY is the clay percentage in soil, and parameters $A=10^{-1.6 \pm 0.9}$, and $B=1.98 \pm 0.7$. This

411 relation gave us $K_{d}=54 \mathrm{ml} \mathrm{g}^{-1}$. Finally, the only difference between Model 1 and Model 2 was

412 that the interaction between the mixing zone and the runoff was neglected in Model $1\left(\mathrm{k}_{\mathrm{a}}=\mathrm{k}_{\mathrm{d}}=\right.$

4130 ), although the attachment and detachment of bacteria to the solid phase, and the infiltration of

414 bacteria in the soil were taken into account in Model $2\left(\mathrm{k}_{\mathrm{a}} \neq 0\right.$ and $\left.\mathrm{k}_{\mathrm{d}} \neq 0\right)$. Hence, in Model 1 , 
all parameters were estimated a priori. None were calibrated. On the contrary, in Model 2, the

416 attachment rate of bacteria at the solid phase, $k_{a}$, had to be estimated from experimental results.

417 Thus, the detachment rate of bacteria, $k_{d}$, was calculated as $k_{d}=k_{a} /\left(\left(\rho / \theta_{s a t}\right) \times K_{d}\right)$.

418 In Figs. 5e-f, the black solid lines correspond to the evolutions over time of $E$. coli export

419 obtained during the two successive simulated rainfalls with Model 1. Except at the beginning of

420 runoff when the simulated concentration is very high because the runoff layer is extremely thin,

421 the numerical results are in good agreement with the experimental results on the sub-plot with

422 raindrop impact, both during the first and the second rainfall (filled triangles in Figs. 5e-f). This

423 result was obtained without calibration. In contrast, the exported bacteria concentrations

424 measured at the outlet of the sub-plot whose surface soil was protected from raindrop impact

425 (empty triangles in Figs. 5e-f) were correctly simulated with Model 2 (grey solid lines in Figs.

$4265 \mathrm{e}-\mathrm{f}$ ) after estimation of the attachment rate $k_{a}$ to the value $0.015 \mathrm{~s}^{-1}$.

\section{4. Discussion}

428 Runoff from manured fields and pastures is known to be an important mechanism by which 429 organisms of faecal origin are transferred to streams highlighting the dominance of diffuse 430 sources of contamination over point sources in rural watersheds (Collins et al. 2005). This is 431 particularly the case in rural areas of developing countries where solid and liquid waste from 432 humans and other animals is released into the environment without treatment. We used field 433 rain simulations and modelling to examine how E. coli are exported from the surface of 434 upland, agricultural soils during runoff events.

\subsection{Effect of raindrop impact on overland flow and soil detachment and entrainment}

436 When the impact of raindrops was reduced, total runoff was on average reduced by $70 \%$

437 during the first rainfall simulation and by 50\% during the second one (Fig. 3a). The purpose 438 of the modelling approach was not to perform a precise calibration of all parameters but rather 
to investigate the behaviour of some of them. Runoff was correctly modelled with a saturated

440 hydraulic conductivity decreasing with time during the rainfall event (Figs. 5a-b). This

441 decreasing conductivity of the soil was faster for the sub-plot without a mosquito net than for

442 the protected sub-plot. This behaviour can be attributed to the formation of more structural

443 crusts on the unprotected soil surface subject to the high kinetic energy raindrop impacts

444 (Mügler et al. 2019).

445 As shown by many previous studies ( Wei et al. 2007; Lacombe et al. 2018), the intensity of 446 rain and soil detachability are directly related. As Ziegler et al. (2000) observed, splash effects

447 dominate over hydrologic processes in soil detachment. Figures 3 and 5 show that rain splash 448 not only enhances runoff generation but also greatly contributes to soil detachment and 449 entrainment. Such a high value of soil detachment rate has already been noticed on bare soils. 450 For example, Patin et al. (2018) obtained in the same catchment a mean soil loss per rainfall event of $154 \pm 53 \mathrm{~g} \mathrm{~m}^{-2}$ on bare soils. This rate dropped to $2 \mathrm{~g} \mathrm{~m}^{-2}$ when the soil was left

452 fallow. In our experiments, the mosquito net, which reduces the splash erosion by $90 \%$, plays 453 the same role as a low vegetation cover.

\subsection{Effect of raindrop impact on bacteria export}

455 Figures 4 and 5e-f show that rain splash also has a strong impact on the export of $E$. coli from

456 the soil surface. The modelling approach used in the work presented here allows the

457 determination of the main processes involved in the transport of bacteria. In this approach

458 (Eqs. 7-9), bacteria are assumed to be released from the surface applied manure into the

459 runoff water. Then, they can interact or not with the soil surface layer. In this zone, called the

460 "soil mixing zone", bacteria can attach or detach from the solid phase. In the sub-plot where

461 the raindrop impact was not reduced (without mosquito net), the high experimental bacteria

462 export was correctly modelled without any exchange of bacteria between runoff and mixing

463 zone. This behaviour is in agreement with experimental and numerical results of Guber et al. 
464 (2009) that we used to validate our modelling approach. Guber et al. (2009) calibrated the

465 mass exchange rate between the runoff and the mixing zone to zero for modelling the export

466 of bacteria from bare plots subject to high rainfall intensities $\left(58<R<73 \mathrm{~mm} \mathrm{~h}^{-1}\right)$.

467 In contrast, less bacteria were exported from the sub-plot where raindrop impact was reduced

468 (with mosquito net). In this case, a part of the bacteria that were released from the manure into

469 the runoff water interacted with the soil surface layer. This lower bacteria export from a

470 protected sub-plot was correctly modelled by taking into account the exchange of bacteria

471 between the overland flow and the soil by attachment and detachment. This behaviour is in

472 agreement with model results of Guber et al. (2011). Indeed, from the calibration of field-

473 scale experiments subjected to rainfall rates lower than $14 \mathrm{~mm} \mathrm{~h}^{-1}$, Guber et al. (2011)

474 concluded that adsorption and desorption of bacteria released from dairy bovine manure were

475 not negligible. The $k_{a} / k_{d}$ ratio that they obtained from calibration $\left(k_{a} / k_{d} \sim 122\right)$ is comparable to

476 the value that we obtained $\left(k_{a} / k_{d} \sim 107\right)$.

477

478

479

480

481

482

483

484

485

486

487

488

\subsection{Effect of successive rainfalls}

As can be seen in Fig. 3a, for each plot, runoff depth increases during successive rainfalls.

This increase was correctly modelled by a decrease of the initial hydraulic conductivity $\mathrm{K}_{0}$ from one rainfall to the next (Table 2 and Figs 5a-b). Effect of successive rainfalls on soil detachment is more contrasted. On one hand, there was a tendency towards decreased soil detachment and entrainment from the sub-plots without mosquito net during successive rainfalls (Fig. 3b). On the other hand, when the impact of raindrops was reduced, soil detachment and entrainment was negligible on the non-amended subplots during both the R1 and R2 rainfalls. It only slightly increased during R2 on the amended Pig A and Chi A subplots perhaps because of the entrainment of some manure by runoff. It is also potentially due to an indirect effect linked to the evolution of the deposit between the two rainfall simulations (e.g. solar radiation, biological activity) that would have made the deposit easier to mobilize. 
When the impact of raindrop was reduced by the mosquito net, the concentration of E. coli in

490 runoff decreased mainly during the first $20 \mathrm{~min}$ of rainfall R2 (Fig. 5e). Thereafter, the

491 concentration decreased only very slightly during the following rainfall R3 (Fig. 5f). When

492 the sub-plots were not protected with a mosquito net, concentrations of $E$. coli in runoff were

493 ten times higher and decreased during the successive rainfalls R2 and R3 (Figs 5e-f).

494 Although the data from the rainfall R3 should be viewed with caution given that only one

495 experiment was possible, the data point towards a decreasing dynamic over successive

496 rainfalls. This decline of the peak bacteria release between the once-wet faecal deposit and

497 subsequent rainfall events has long been observed (e.g. Kress and Gifford 1984). It has been

498 attributed to the leaching effect of the first rainfall on bacteria in the faecal deposit.

\section{5. Conclusion}

500 Rainfall simulation experiments at the plot scale carried out with or without raindrop impact on 501 bare or amended soils led to the following conclusions:

- Runoff production, soil detachment and entrainment and E. coli export are strongly enhanced by raindrop impact. When the impact of raindrops was reduced with a mosquito net, soil erosion was on average reduced by $90 \%$ and E. coli export from the amended soil surface was on average 3 to 8 times lower. These results underline the strong impact of the splash effect on the export of E. coli from the soil surface.

- The temporal evolution of runoff, soil and E. coli exports during two successive rainfall simulations were correctly modelled with a physics-based approach with a soil hydraulic conductivity and a soil erodibility that exponentially decreased over time of exposure to rainfall. These decreasing parameters model the splash effect on the soil surface properties. rainfall on bacteria in the faecal deposit. 
- When the impact of raindrops was reduced, the lower bacteria export from the protected soil was correctly modelled by taking into account the exchange of bacteria between the overland flow and the soil by attachment and detachment.

518 These results highlight the strong mobilization and transport of faecal indicator bacteria from

519 steep slopes under high intensity rainfall such as usually occur in rural Southeast Asia. The

520 links between land cover, or vegetation and soil erosion have been previously identified (i.e.

521 Lacombe et al. 2018) and recent work demonstrated the importance of vegetation cover in

522 reducing the export of soil microbial communities from soils (Le et al. 2020). The work

523 presented here builds on this work and shows that by reducing the splash effect, through low

524 cover, such as surface vegetation, can significantly reduce microbial pathogen dissemination

525 and, by extension, the contamination of stream waters. This is particularly important in areas

526 where access the adequate sanitation is limited or non-existent and where untreated surface

527 water is used for domestic requirements.

528 


\section{Declarations}

Ethics approval and consent to participate

533 Not applicable

\section{Consent for publication}

535 Not applicable

\section{Availability of data and materials}

537 The datasets used and analysed during the current study are available from the corresponding 538 author on reasonable request.

\section{Competing interests}

540 The authors declare that they have no competing interests.

\section{$541 \quad$ Funding}

542 This research was funded by French National Research Agency (TecItEasy project; ANR-13543 AGRO-0007), the French Institut de Recherche pour le Développement (IRD) through UMR 544 iEES-Paris, UMR GET and the Pastek program of the GIS-Climat.

\section{Authors' contributions}

546 All authors contributed to the work presented in the manuscript. Olivier Ribolzi and Emma

547 Rochelle-Newall and Oloth Sengtaheuanghoung contributed to the study conception and

548 design. Material preparation and field data collection were performed by Jean-Louis Janeau,

549 Thierry Henri-des-Tureaux, Keooudone Latsachack, Marion Viguier, Christian Valentin and

550 Olivier Ribolzi. Laboratory analysis were conducted by Chanthamousone Thammahacksa,

551 Emilie Jardé, Marion Viguier and Emma Rochelle-Newall. Modelling was performed by

552 Claude Mügler. The first draft of the manuscript was written by Claude Mügler, Olivier

553 Ribolzi and Emma Rochelle-Newall, all authors commented on previous versions of the

554 manuscript. All authors read and approved the final manuscript. 


\section{Acknowledgments}

556 The authors would like to thank the Lao Department of Agriculture Land Management

557 (DALAM) and the M-Tropics observatory (Multiscale TROPIcal Catchments;

558 https://mtropics.obs-mip.fr) for their support.

559

560 


\section{References}

562 Armenise E, Simmons RW, Ahn S, Garbout A, Doerr SH, Mooney SJ, Sturrock CJ, Ritz K 563 (2018) Soil seal development under simulated rainfall: Structural, physical and hydrological 564 dynamics. J Hydrol 556:211-219

565 Assouline S, Mualem Y (1997) Modeling the dynamics of seal formation and its effect on 566 infiltration as related to soil and rainfall characteristics. Water Resour. Res. 33(7):1527-1536

567 Assouline S (2004) Rainfall-induced soil surface sealing: A critical review of observations, 568 conceptual models, and solutions. Vadose Zone J 3(2):570-591

569 Boithias L, Choisy M, Souliyaseng N, Jourdren M, Quet F, Buisson Y, Thammahacksa C, 570 Silvera N, Latsachack KO, Sengtaheuanghoung O, Pierret A, Rochelle-Newall E, Becerra S, 571 Ribolzi O (2016) Hydrological regime and water shortage as drivers of the seasonal incidence 572 of diarrheal diseases in a tropical montane environment. PLoS Negl Trop Dis $573 \quad 10(12): \mathrm{e} 0005195$

574 Causse J, Billen G, Garnier J, Henri-des-Tureaux T, Olasa X, Thammahacksa C, Latsachak 575 KO, Soulileuth B, Sengtaheuanghoung O, Rochelle-Newall E, Ribolzi O (2015) Field and 576 modelling studies of Escherichia coli loads in tropical streams of montane agro-ecosystems. J 577 Hydro-environ Res 9:496-507

578 Cho KH, Pachepsky YA, Oliver DM, Muirhead RW, Park Y, Quilliam RS, Shelton DR, 2016.

579 Modeling fate and transport of fecally-derived microorganisms at the watershed scale: State 580 of the science and future opportunities. Water Res 100:38-56

581 Collins R, Elliott S, Adams R (2005) Overland flow delivery of faecal bacteria to a headwater 582 pastoral stream. J Appl Microbiol 99:126-132

583 Gagliardi JV, Karns JS (2000) Leaching of Escherichia coli O157: H7 in diverse soils under various agricultural management practices. Appl Environ Microbiol 66(3):877-883 
Guber AK, Pachepsky YA, Yakirevich AM, Shelton DR, Sadeghi AM, Goodrich DC,

586 Unkrich CL (2011) Uncertainty in modelling of faecal coliform overland transport associated

587 with manure application in Maryland. Hydrol Process 25(15):2393-2404

588 Guber AK, Shelton DR, Pachepsky YA, Sadeghi AM, Sikora LJ (2006) Rainfall-induced

589 release of fecal coliforms and other manure constituents: Comparison and modeling. Appl and

590 Environ Microbiol 72(12):7531-7539

591 Guber AK, Yakirevich AM, Sadeghi AM, Pachepsky YA, Shelton DR (2009) Uncertainty

592 Evaluation of Coliform Bacteria Removal from Vegetated Filter Strip under Overland Flow

593 Condition. J Environ Qual 38(4):1636-1644

594 Ishii S, Sadowsky MJ (2008) Escherichia coli in the environment: implications for water

595 quality and human health. Microbes Environ 23:101-108

596 Jamieson R, Gordon R, Joy D, Lee H (2004) Assessing microbial pollution of rural surface

597 waters - A review of current watershed scale modeling approaches. Agric Water Manag

$598 \quad 70(1): 1-17$

599 Jamieson R, Joy DM, Lee H, Kostaschuk R, Gordon R (2005) Transport and deposition of

600 sediment-associated Escherichia coli in natural streams. Water Res 39(12):2665-2675

601 Janeau JL, Bricquet JP, Planchon O, Valentin C (2003) Soil crusting and infiltration on steep

602 slopes in northern Thailand. European J Soil Sci 54(3), 543-553.

603 Janeau JL, Gillard LC, Grellier S, Jouquet P, Le TPQ, Luu TNM, Ngo QA, Orange D, Pham

604 DR, Tran DT, Tran SH, Trinh AD, Valentin C, Rochelle-Newall E (2014) Soil erosion,

605 dissolved organic carbon and nutrient losses under different land use systems in a small

606 catchment in northern Vietnam. Agri Water Manag 146:314-323

607 Kinnell PI (1993) Runoff as a factor influencing experimentally determined interrill

608 erodibilities. Australian J Soil Sci 31:333-342 
609 Kinnell PIA (2005) Raindrop-impact-induced erosion processes and prediction: a review.

610 Hydrol Process 19(14):2815-2844

611 Kollet S, Sulis M, Maxwell RM, Paniconi C, Putti M, Bertoldi G, Coon ET, Cordano E,

612 Endrizzi S, Kikinzon E, Mouche E, Mügler C, Park YJ, Refsgaard JC, Stisen S, Sudicky E

613 (2017) The integrated hydrologic model intercomparison project, IH-MIP2: A second set of

614 benchmark results to diagnose integrated hydrology and feedbacks. Water Resour Res

$615 \quad 53(1): 867-890$

616 Kress M, Gifford G (1984) Fecal coliform release from cattle fecal deposits. Water Resour

617 Bull 20(1):61-66

618 Lacombe G, Valentin C, Sounyafong P, de Rouw A, Soulileuth B, Silvera N, Pierret A,

619 Sengtaheuanghoung O, Ribolzi O (2018) Linking crop structure, throughfall, soil surface

620 conditions, runoff and soil detachment: 10 land uses analyzed in Northern Laos. Sci Total

621 Environ 616:1330-1338

622 Le HT, Rochelle-Newall E, Ribolzi O, Janeau JL, Huon S, Latsachack K, Pommier T (2020)

623 Land use strongly influences soil organic carbon and bacterial community export in runoff in

624 tropical uplands. Land Degrad \& Dev 31:118-132

625 Luk SH (1979) Effect of soil properties on erosion by wash and splash. Earth Surf Process

$626 \quad 4: 241-255$

627 Martinez G, Pachepsky YA, Whelan G, Yakirevich AM, Guber A, Gish TJ (2014) Rainfall-

628 induced fecal indicator organisms transport for manured fields: Model sensitivity analysis.

629 Environ Int 63:121-129

630 Mügler C, Planchon O, Patin J, Weill S, Silvera N, Richard P, Mouche E (2011) Comparison

631 of roughness models to simulate overland flow and tracer transport experiments under

632 simulated rainfall at plot scale. J Hydrol 402(1):25-40 
633 Mügler C, Ribolzi O, Janeau JL, Rochelle-Newall E, Latsachach K, Thammahacksa C,

634 Viguier M, Jarde E, Henri-Des-Tureaux T, Sengtaheuanghoung O, Valentin C (2019)

635 Experimental and modelling evidence of short-term effect of raindrop impact on hydraulic

636 conductivity and overland flow intensity. J Hydrol 570:401-410

637 Muirhead RW, Collins RP, Bremer PJ (2006) Interaction of Escherichia coli and soil particles

638 in runoff. Appl and Environ Microbiol 72(5):3406-3411

639 Pachepsky YA, Sadeghi AM, Bradford SA, Shelton DR, Guber AK, Dao T (2006) Transport

640 and fate of manure-borne pathogens: Modeling perspective. Agri Water Manag 86(1-2):81-

64192.

642 Patin J, Mouche E, Ribolzi O, Sengtahevanghoung O, Latsachak KO, Soulileuth B, Chaplot

$643 \mathrm{~V}$, Valentin C (2018) Effect of land use on interrill erosion in a montane catchment of

644 Northern Laos: An analysis based on a pluri-annual runoff and soil loss database. J Hydrol $645 \quad 563: 480-494$.

646 Quansah C (1981) The effect of soil type, slope, rain intensity and their interactions on splash 647 detachment and transport. J Soil Sci 32(2):215-224

648 Ribolzi O, Evrard E, Huon S, Rochelle-Newall E, Henri-des-Tureaux T, Silvera N,

649 Thammahacksac C, Sengtaheuanghoung O (2016) Use of fallout radionuclides $\left({ }^{7} \mathrm{Be},{ }^{210} \mathrm{~Pb}\right)$ to 650 estimate resuspension of Escherichia coli from streambed sediments during floods in a 651 tropical montane catchment. Environ Sci Pollut Res 23(4):3427-3435

652 Ribolzi O, Evrard O, Huon S, de Rouw A, Silvera N, Latsachack KO, Soulileuth B, Lefèvre I, 653 Pierret A, Lacombe G, Sengtaheuanghoung O, Valentin C (2017) From shifting cultivation to 654 teak plantation: effect on overland flow and sediment yield in a montane tropical catchment. 655 Scientific Reports 7(1):3987 
656 Ribolzi O, Patin J, Bresson LM, Latsachack KO, Mouche E, Sengtaheuanghoung O, Silvera

657 N, Thiebaux JP, Valentin C (2011) Impact of slope gradient on soil surface features and 658 infiltration on steep slopes in northern Laos. Geomorphology 127(1-2):53-63

659 Rochelle-Newall E, Nguyen TMH, Le TPQ, Sengteheuanghoung O, Ribolzi O (2015) A short 660 review of fecal indicator bacteria in tropical aquatic ecosystems: knowledge gaps and future 661 directions. Front Microbiol 6:308

662 Rochelle-Newall E, Ribolzi O, Viguier M, Thammahacksa C, Silvera N, Latsachack KO, 663 Rinh PD, Naporn P, Hai Tran S, Soulileuth B, Hmaimum N, Sisouvanh P, Robain H, Janeau 664 JL, Valentin C, Boithias L, Pierret A (2016) Effect of land use and hydrological processes on 665 Escherichia coli concentrations in streams of tropical, humid headwater catchments. Scientific 666 Reports 6:32974

667 Rosebury T (1962) Microorganisms indigenous to man. New York: McGraw-Hill Co 668 Silburn DM, Connolly RD (1995) Distributed parameter hydrology model (ANSWERS) 669 applied to a range of catchment scales using rainfall simulator data I: Infiltration modelling 670 and parameter measurement. J Hydrol 172(1):87-104

671 Tatard L, Planchon O, Wainwright J, Nord G, Favis-Mortlock D, Silvera N, Ribolzi O, 672 Esteves M, Huang CH (2008) Measurement and modelling of high-resolution flow-velocity 673 data under simulated rainfall on a low-slope sandy soil. J Hydrol 348(1-2):1-12

674 Unc A, Goss MJ (2004) Transport of bacteria from manure and protection of water resources. 675 Appl Soil Ecol 25(1):1-18

676 Valentin C, Agus F, Alamban R, Boosaner A, Bricquet JP, Chaplot V, de Guzman T, de 677 Rouw A, Janeau JL, Orange D, Phachomphonh K, Phai Do Duy, Podwojewski P, Ribolzi O, 678 Silvera N, Subagyono K, Thiébaux J, Toan T, Vadari T (2008) Runoff and sediment losses 679 from 27 upland catchments in Southeast Asia: Impact of rapid land use changes and 680 conservation practices. Agric Ecosyst Environ 128:225-238 
681 Wei W, Chen L, Fu B, Huang Z, Wu D, Gui L (2007) The effect of land uses and rainfall

682 regimes on runoff and soil erosion in the semi-arid loess hilly area, China. J Hydrol 335(3-

683 4):247-258

684 Weill S, Mouche E, Patin J (2009) A generalized Richards equation for surface/subsurface

685 flow modelling. J Hydrol 366(1):9-20

686 Wilkinson J, Jenkins A, Wyer M, Kay D (1995) Modeling fecal-coliform dynamics in streams

687 and rivers. Water Res 29(3):847-855

688 Woolhiser DA, Smith RE, Goodrich DC (1990) KINEROS, a kinematic runoff and erosion

689 model: Documentation and user manual. U.S Department of Agriculture, Agricultural

690 Research Service, ARS-77, 130pp

691 World Health Organisation (2014) Progress on Drinking Water and Sanitation, WHO Library

692 Cataloguing-in-Publication Data, Avenue Appia, 1211 Geneva 27, Switzerland

693 Ziegler AD, Sutherland RA, Giambelluca TW (2000) Partitioning total erosion on unpaved

694 roads into splash and hydraulic components: The roles of interstorm surface preparation and

695 dynamic erodibility. Water Resour Res 36(9):2787-2791 
Figure captions:

697

$698 \quad$ Fig. 1

699 Study site: (a) Aerial view of the Houay Pano catchment (white dotted polygon) and location of

700 the experimental site (white rhombus); (b) Picture showing an overview of the hillslope and the

701 experimental site with the rainfall simulator tent on the right

702

703

Fig. 2

704 Experimental design: (a) image of one 1- $\mathrm{m}^{2}$ metallic frame divided into two sub-plots without

705 mosquito net (left) and with mosquito net (right); (b) Diagram showing the nine plots (pairs of 9

706 sub-plots without mosquito net shown in white, associated with 9 sub-plots covered with

707 mosquito net shown in colour) divided in triplicated treatment groups (A, B, C): controls with

708 no amendments (Ref A, Ref B, and Ref C) or amended with pig manure (Pig A, Pig B, and

709 Pig C) or poultry manure (Chi A, Chi B, and Chi C); (c) Image of one sub-plot partially covered

710 with disconnected small patches of chicken manure ; (d) Chronological sequence for the three

711 rainfall simulations (R1, R2 and R3) and time of amendment with pig or chicken manure

712

713

Fig. 3

714 Bar plots showing cumulated (a) runoff depth and (b) soil erosion from the eighteen $0.5 \mathrm{~m}^{2}$

715 sub-plots (i.e. nine without plus nine with mosquito net) divided into triplicated treatment

716 groups (A, B, C). Controls with no amendments (Ref) or amended with pig manure (Pig) or

717 poultry manure (Chi). Measurements were conducted during the first rainfall simulation (R1,

718 before manure application) and the second rainfall simulation (R2, after manure application)

719

720 


\section{$721 \quad$ Fig. 4}

722 E. coli concentration in runoff water from both sub-plots without mosquito net (left side, with 723 splash effect) and with mosquito net (right side, with limited splash effect) for the triplicated 724 plots Ref, Pig, and Chi for rainfall simulation R2

\section{Fig. 5}

727 Evolution over time on plot Chi A of the runoff coefficient (Runoff/Rainfall) obtained during R2 (a) and R3 (b); the sediment outputs obtained during R2 (c) and R3 (d); E. coli concentrations obtained during R2 (e) and R3 (f). In each figure, empty and filled symbols

730 correspond to the experimental results for the sub-plots with and without a mosquito net,

731 respectively. Solid lines correspond to the modelled evolutions with mosquito net (grey) and 732 without mosquito net (black) 